\title{
It Wasn't Just Emily Davison! Sport, Suffrage and Society in Edwardian Britain
}

Joyce Kay

The suffragette Emily Davison was killed by King George V's horse during the 1913 Epsom Derby while trying to draw attention to the campaign for women's suffrage. However, this much publicised and shocking incident was not the only connection between sport and political protest in the early twentieth century. This paper will show how British suffragettes carried out a series of violent acts against sport and sportsmen that were unparalleled in the English speaking world. At the same time it will demonstrate that female suffragists, like many Edwardian women, took part in a wide variety of sports, suggesting that it was possible to be both a feminist and a sportswoman.

\section{Introduction}

The women's suffrage movement and women's sport seldom inhabit the same academic territory. Social and political historians who have written extensively on the battle for the vote and scrutinised the lives of the most prominent activists in the Edwardian period have also uncovered links between female suffrage and art, vegetarianism, and drama but have failed to make any connection with sport and leisure. [1] Sports historians have put forward two schools of thought with regard to women's sport in the years 1870-1914. The first postulates that sport acted as a means of emancipating women. The second, however, has tended to deny any specific association between sport, feminist thought and women's suffrage, suggesting, for example, that most sportswomen, even the pioneers of women's physical education, had 'little interest in the franchise issue.' [2]

The only event that may connect the two topics in the minds of British scholars and the general population is the much publicised injury and death of the militant suffragette Emily Davison during the 1913 Epsom Derby. She rushed onto the track and into the path of a horse belonging to King George V, was knocked down and never regained consciousness. It is generally believed that she deliberately targeted the animal as a protest to the King. [3] Her 
dignified funeral procession through the London streets was accompanied by concerns that the occasion might be disrupted, 'the manner of the death ... (having been) ... such as to arouse a bitter feeling among what is termed the "sporting element” of the population'. Some racing men indeed voiced their opinions: one suffrage leader was shocked to hear them shouting “the King's ‘orse!”, while The Times reported cries of “three cheers for the King's jockey.” [4] The entire incident shocked the Edwardian public and immortalised the victim, but it was not an isolated act of violence between suffragettes and the sporting community.

This paper will consider the ways in which sport and suffrage were linked, firstly by examining how sport featured in the arson campaign carried out in 1913-14 by the militant suffrage society, the Women's Social and Political Union (WSPU), and secondly by analysing new evidence on the role of sport and recreation in the lives of British suffrage women.

\section{Background to Militancy}

The fight for women's suffrage in Britain was almost 50 years old by the time Emily Davison made her fatal protest and its history has been charted in numerous books and articles. [5] The first 40 years had seen petitions, speeches, processions and banners - all very genteel and constitutional - but attitudes hardened after the formation in 1903 of the WSPU, led by Emmeline Pankhurst and her eldest daughter, Christabel. The first militant acts, resulting in arrests and imprisonment, took place in 1905 and over the next few years hundreds of prison terms were served by well dressed, well spoken, largely middle-class women who eventually resorted to bombs, hoaxes and arson - 'classic acts of terrorism' - in an effort to be included in the governance of the country. A file in the National Archives even suggests there was a suffragette plot to assassinate Prime Minister Asquith and Davison has recently been compared to a modern day suicide bomber. [6]

By the time the first hunger strike occurred in 1909, the situation had deteriorated into a war between militant suffragettes and the state. The Asquith government responded by sanctioning forcible feeding, a tactic that would not surprise feminist historians who have 
identified, and written widely on, the theme of male power over the female body. [7] A medical profession that had increasingly sought to control and regulate women's bodies at the end of the nineteenth century may have experienced little compunction some years later in employing a range of invasive techniques intended to prevent suffragettes from becoming martyrs to the cause. That this could be condoned in a 'civilised' state says much about the attitude of a society that was still essentially patriarchal. Hunger strikes and their consequences also ensured that some women never recovered their health; several died prematurely from injuries sustained in jail. It is hardly surprising that the most militant suffragettes saw male politicians and the male establishment as suitable targets for retaliation.

It should be remembered, however, that only the WSPU undertook acts of militancy: the other British suffrage societies stuck to conventional, constitutional, or at least passive, methods of protest. More significantly, perhaps, these levels of militancy were entirely absent from the women's suffrage movements in Australia, New Zealand and America. Adela Pankhurst, youngest daughter of Emmeline, emigrated to Australia in 1914, at a time when her mother was championing attacks on property and resorting to hunger strikes, only to discover that 'women have been voting here since the first federal election in 1903 without all the militant fuss.' [8] Many had been granted a vote in state elections even earlier, starting with South Australia in 1894. New Zealand women had also been enfranchised (1893) - the first in the world to be granted the national vote - without needing to declare war on the state. After these victories on home soil, numerous suffrage activists from both countries turned their attention to the British situation. In 1908, under the auspices of the Australian and New Zealand Women Voters' Association, they marched in a London suffrage procession carrying a banner in which a daughter figure, representing the Commonwealth of Australia, addressed mother Britannia with the words, ‘Trust the Women, Mother, As I Have Done.’ [9]

The vast majority of American female suffragists also declined to adopt militant methods. As in Britain, the campaign for a national vote only bore fruit after World War I although many western states from Kansas to California had amended their suffrage legislation to include women before 1914. During the pre-war period some tactics, such as 
suffrage parades, colours and demonstrations, were borrowed from the British example but 'the emphasis was on crowd-pleasing spectacle rather than militant confrontation.' [10] In general, American women listened, filling New York’s Carnegie Hall in1909 to hear Emmeline Pankhurst speak, but declined to follow. The arrival from Britain, in 1912, of Alice Paul, an American with experience of WSPU militancy, inspired a few to chain themselves to fences and burn watch fires in front of the White House - Paul herself was imprisoned three times for picketing - but the overwhelming stateside attitude to the WSPU approach was negative, particularly amongst suffrage leaders. Harriet May Mills, president of the New York State Suffrage Association, said, 'I don't believe in militant methods. I cannot see that they have helped in England (sic) and I am sure they have been a detriment to us here.' [11] Anna Howard Shaw, president of the North American Woman Suffrage Association, wrote in 1914, 'there has never been any sympathy among American suffragists for the militant suffrage movement in England and personally I am wholly opposed to it.' Militant methods were, she stated, 'undignified, unworthy - in other words, un-American.'[12] Alice Stone Blackwell, a prominent US suffragist and editor of Woman's Journal - a suffrage mouthpiece - thought that American women should be kindled to greater efforts by Emily Davison's unselfishness and courage but noted that 'we have no call to use like methods.' [13] Britain, it seems, was set apart in the English-speaking world by the sheer ferocity of its suffrage campaign, its emphasis on criminal acts and its espousal of tactics which could be classed as 'terrorism.'

\section{The Militant Campaign}

The suffragette campaign of arson and vandalism began in February 1913 and continued until the outbreak of war in August 1914. The catalyst for this sustained period of law-breaking had been the failure in January 1913 of the latest in a long series of attempts to obtain votes for women through the parliamentary process, the twentieth Bill to be proposed and rejected. After this setback Emmeline Pankhurst advocated damage to property as a further step in 'persuading' politicians and populace to change their views. The destruction began immediately with window-breaking in London's West End, the vandalising of hundreds of 
orchids at Kew Gardens and the smashing of a jewel case at the Tower of London. Thereafter, tactics changed. Instead of raids carried out in broad daylight, attracting publicity but also immediate apprehension and imprisonment, the new 'guerilla warfare' took place secretly after dark and resulted in far fewer arrests. It has therefore been difficult to estimate how many women were involved in this, the most violent, phase of the WSPU struggle but it seems that the more extreme forms of violence were the work of a small inner core of militants. As few as 100 activists, supported by a network of helpers, may have been responsible for fire raising and planting home-made bombs; over 100 incidents may have been carried out by only 17 women. [14]

The first night time sorties were aimed at sport. During February and March golf courses were attacked with corrosive liquids such as acid, which destroyed the greens, or digging implements, used to make holes in the turf or to carve 'Votes for Women' in the grass. Between three and nine greens were damaged on each course, beginning around Birmingham and spreading across Wales, East Anglia, Yorkshire and the south-east. Even Scotland, the home of golf, where women were allegedly more welcome on the links was not immune to suffragette violence although it remained a rare occurrence there. [15] Large circular holes were cut in three greens at Kilspindie in September 1913 and damage inflicted on a further six at the Braid Hills course in Edinburgh the following June. Scottish suffragists, however, preferred a different approach, with golfing politicians holidaying north of the border targeted more regularly in 1912 and 1913 than the links on which they played. Prime Minister Asquith was verbally and physically attacked on at least four occasions during this period, once while playing a round with his Home Secretary, Reginald McKenna. [16] Press reports of these episodes were limited and no charges were brought.

Coverage of golf course damage, however, was extensive. The daily newspapers railed at these 'outrages' while the weekly golfing magazine, Golf Illustrated, and the suffragettes traded blows, the latter's view encapsulated in the statement 'a golfer is also a man and a citizen, and because he is a man and a citizen, he is responsible for the way in 
which the Government are treating the women and the Women's Cause.' A stirring poem was printed to justify the actions of the vandals, one verse of which declaimed,

\author{
Ruthless are the hearts that burn \\ For the cause; \\ Even golf must serve its term \\ For the cause; \\ Man the tyrant must be floored, \\ So, the Royal and Ancient sward, \\ Heroines have hacked and scored \\ For the Cause [17]
}

After a few weeks sportsmen and correspondents began to treat the matter with disdain, penning 'amusing' ditties or ridiculing the suffragettes in cartoons and anecdotes. One, in the Badminton Magazine, recounted a tale from Northwood Golf Club where the peace of the clubhouse was disturbed by 'thunderous noises' and 'unparliamentary language.' ““Good heavens!” said one of the non-playing golfers. "I suppose some Suffragist hooliganesses have turned up this afternoon!” “No sir I don’t think so” remarked the steward quietly. "From what I can hear of things, it's only Mr X approaching the $16^{\text {th }}$.”' Despite these attempts at humour, golf course damage was said to rival setting fire to pillar boxes as the most hated crime in the eyes of the general population. [18]

The first arson attacks on sports premises also took place in February and March 1913. The pavilion of Old Manchester golf club was set alight but suffered little damage. A wooden structure belonging to a bowling club at Heaton Park, Newcastle was burnt down and the fire brigade found a card nearby with the words 'No peace until votes for women.' The Times reported the arrest of a woman, aged 30-35, carrying paraffin and wood shavings within the grounds of the All England Lawn Tennis Club at Wimbledon. She had been spotted by a groundsman while climbing over a hedge shortly before midnight. She refused to give her name or any information and was later sentenced to two months imprisonment. The most publicised of these early incidents saw the arrest of Olive Hockin for an arson attack on Roehampton Golf Club. A copy of the WSPU newspaper, The Suffragette, with her 
name and address pencilled on it, was found at the crime scene and when police raided her flat they found wire cutters, a new hammer, a gallon tin of paraffin, bottles of corrosive liquid and a false car number plate. She was sentenced to four months in prison.

Intimidation became another ploy in early March when the president of the Oxford University boat club received an anonymous letter from militant suffragists aiming to disrupt the annual contest against Cambridge on the River Thames. It was believed that they would try to interrupt the race by putting out in small boats, and members of local rowing clubs were asked to patrol the river banks to prevent any incursions. In the event, nothing untoward happened. The remainder of the year, however, saw considerable damage to property and numerous foiled plots, with few sports immune from attack. Horseracing, cricket, lawn tennis, bowls, football, rowing, swimming, billiards, and rugby premises all suffered during the campaign. C.J. Bearman, in an article on suffragette violence, calculated that 51, nearly one-sixth of all incidents, were carried out against sports targets. Private sports pavilions and boathouses accounted for the third highest category (34) after private houses/hotels/domestic offices (96) and haystacks/farm buildings (36). Arson attempts on sports grandstands (17) ranked alongside industrial premises (17) and above schools/colleges (16). [19]

Table 1 lists the most important suffragette attacks on sport over a period of nine months in 1913 when this form of militancy was at its height. The most devastating was the fire at Hurst Park racecourse in June, following the death of Emily Davison. It was carried out by Clara Giveen and 'Kitty Marion’ (real name Katharina Schafer) and the venue had been selected because 'it would make a most appropriate beacon.' [20] According to The Times, two stands, the stewards' box, press box, kitchen and luncheon rooms were all destroyed and there was slight damage to two further stands. Estimates put the cost of repairs as high as $£ 12,000$ (around $£ 900,000$ in present terms) and they were still ongoing at the outbreak of war 14 months later. [21] The same newspaper gave a particularly graphic account of the final major incident of the year, a plan to destroy the County grandstand at Aintree racecourse in December. A policeman on guard noticed a strong smell of paraffin coming from within the building. On investigation, he 
found quantities of inflammable material on the staircase and, on the floor of the stewards' room, a can of paraffin trickling into a basket of wadding on top of which sat a flaming candle. It had burned down to the last inch by the time it was discovered. [22]

Some of those affected by the suffragettes' action took the law into their own hands.

After the burning of an Oxford boathouse, a nearby suffrage office was wrecked by a mob, said to be undergraduates. Ironically, the building was the local headquarters of the National Union of Suffrage Societies, the largest suffrage organisation but strictly non-militant. Its members could not, therefore, have been responsible for the boathouse fire. When the sports pavilion belonging to Bristol University was burned down, a crowd of students marched on the local suffragette office, smashed windows and set fire to furnishings, apparently egged on by a crowd of onlookers. [23] Others merely voiced disapproval of the property attacks. At a meeting following the destruction of the Tunbridge Wells cricket pavilion Sir Arthur Conan Doyle, creator of Sherlock Holmes, referred to the militants as 'female hooligans' and condemned those who supplied them with money as 'if possible, a more contemptible kind of person.' [24]

Table 1 Suffragette Damage to Sports Venues, April - December 1913

\begin{tabular}{|c|c|c|}
\hline Date & $\underline{\text { Venue }}$ & Intended or Actual Damage \\
\hline \multirow[t]{11}{*}{ April } & Ayr racecourse & Grandstand destroyed - c £3,000 damage \\
\hline & Cardiff racecourse & Attempt to damage \\
\hline & Kelso racecourse & Attempt to burn down grandstand \\
\hline & Tunbridge Wells & $\begin{array}{l}\text { Cricket pavilion and records of Kent CCC destroyed - } \\
\text { c } £ 1,200 \text { damage }\end{array}$ \\
\hline & Bellahouston, Glasgow & Bowling green damaged \\
\hline & Dundee & Attempt to burn down lawn tennis pavilion \\
\hline & Crystal Palace & Plot to destroy grandstands before FA cup-tie \\
\hline & Perthshire & Cricket pavilion destroyed - c $£ 1,250$ damage \\
\hline & Preston North End & Attempt to burn down grandstand \\
\hline & Hampton Court & Boathouse destroyed - c £3,500 damage \\
\hline & Birmingham & Boathouse destroyed \\
\hline \multirow[t]{5}{*}{ May } & Birmingham & Tennis court destroyed by acid \\
\hline & Dundee & Bomb found in billiard room - no damage \\
\hline & Fulham & Bowling green pavilion destroyed \\
\hline & Nottingham & Boathouse on River Trent destroyed - c £2,000 damage \\
\hline & Cambridge & Attempt to burn pavilion at University football ground \\
\hline June & Oxford & Rough’s boathouse destroyed - c £3,000 damage \\
\hline
\end{tabular}


North Middlesex

Hurst Park racecourse

July/August

Dorking

Liverpool

September

Norwood
Bridge of Allan
Plumstead

October

Bristol

Newcastle

November

Headingley

Stockton-on-Tees

Catford

Bristol

Blackburn
Cricket club pavilion destroyed - c $£ 1,000$ damage

Grandstands, press box destroyed - c £12,000 damage

Golf course damaged

Sports pavilion damaged

Bowling green damaged

Bowling green damaged

Football grandstand destroyed - c £1,000 damage

University sports pavilion destroyed - c £2,000 damage

Golf course damaged

Attempt to burn down rugby football grandstand

Attempt to burn down racecourse grandstand

Bowling green pavilion destroyed - $\mathrm{c} £ 1,500$ damage

Boathouse burned - c $£ 300$ damage

Attempt to burn down football grandstand

Attempt to burn down County Stand, Aintree racecourse

December Liverpool

Sources: Times; Suffragette, 26 December, 1913 - A Year’s Record, 258; Leneman;

Golf Illustrated; Bearman

Although further arson attacks took place in the first half of 1914, the monthly average fell and there were proportionately far fewer on sports premises than in the previous year. The clubhouse at Surbiton golf club was damaged in March (estimated cost £800), the grandstand and offices at Birmingham racecourse and a nearby cricket pavilion were destroyed by fire in May and a tennis club pavilion set on fire at Nottingham in June. A number of golf courses continued to be damaged by acid but this form of violence was less apparent in 1914. Many reasons can be suggested for the decline in property damage including lack of available personnel to carry out attacks, either through imprisonment, ill health or lying low; fewer suitable targets, perhaps because of an increase in caretakers and night watchmen; or a change in tactics by WSPU organisers. It is also possible that arson was over-reported in 1913 - The Times pointed out that some incidents blamed on the militants were simply everyday crimes and cited the destruction of haystacks by two drunks and the torching of industrial premises by their owner in an attempt to defraud insurers. In turn, the WSPU leadership may have claimed every suspicious blaze in order to inflate the figures. [25] 
In the United States the response to suffrage violence in Britain was highly critical. Emmeline Pankhurst who had made several successful visits to the country to speak at suffrage meetings found herself the object of negative media attention during her 1913 tour. No American suffrage society, by word or deed, followed her appeal to physical force and although US suffragists adopted some attention-grabbing tactics from Britain, the extreme militancy of the WSPU estranged many more. The only evidence that has been uncovered of a direct link between American female suffragists and sport is of a lighthearted and celebratory nature. On the annual New York Suffrage Day in May 1915, women attended the baseball game between the Giants and the Cubs at the Polo Grounds and unfurled banners with slogans such as 'We'd Like Our Innings.' [26] British militants had abandoned such innocent ploys more than two years earlier.

\section{Sporting Targets?}

Connections between the WSPU and the sports community prompt two questions: firstly, why did so many sports venues suffer damage and secondly, were they deliberately targeted by suffrage campaigners? Perhaps the most plausible reason why sports premises were attacked was that they were very easy targets, nearly always empty and unguarded at night. Many were located in suburban or semi-rural areas: Bearman notes that most incidents of violence towards property took place in suburbs and in his view, militancy tended to follow the lines of least resistance. Targets were therefore easily flammable, easily accessible and not well protected; they were also situated in areas to which suffragettes able and willing to engage in arson could travel without difficulty. [27] Applying these criteria to sports premises, private sports pavilions often fitted the bill, being of wooden construction, relatively isolated by grounds even if suburban, and lacking adequate defence against intruders. Press reports certainly suggest that few women were caught attacking such buildings.

While it is more likely that the type of pavilion selected was dependent on the geographical and personnel factors mentioned above, it is possible that the more masculine sports were particularly singled out for attention. Cricket, rowing and billiards were almost exclusively male pursuits beyond the country house and its park and there was limited female 
participation in bowls. These four account for two-thirds of the damage inflicted on private sports club premises in Table 1 . However, there is no evidence that targets were definitely gender specific; tennis and golf clubs, where female membership was more likely, were not immune from attack. Yet Hannah Mitchell, a WSPU activist, undoubtedly approved of the consequences to golf course damage as she later wrote that 'there did seem something to laugh at in the idea of the plus-foured MP toddling along to his favourite golf links, to find, cut in the sacred sward, the terrible slogan "Votes for Women”'. [28] This statement suggests that influencing politicians, rather than upsetting ordinary club members, male or female, was uppermost in the minds of the suffragettes.

The targeting of grandstands was different. Large fires were spectacular if successful and attracted considerable publicity but they may have been singled out for their media impact rather than a connection with sport per se. The stands themselves were expensive to replace and damage caused severe disruption - the destruction at Hurst Park racecourse was a prime example - but other large buildings such as railway stations, churches and mansions were also selected during the arson campaign, probably for reasons already suggested: they were isolated, frequently unprotected, and accessible. The risk of discovery, however, appeared to be higher for grandstand arsonists than for those who attacked private clubs. 'Kitty Marion’ was jailed for three years for her involvement at Hurst Park; she only served part of the sentence but was forcibly fed 232 times over a period of four months. Four women, including two in their sixties, were tried for a failed attempt on the grandstand at Kelso racecourse in April 1913. Three were imprisoned (but later released after going on hunger strike) and the same fate befell two suffragettes who were caught with matches, cotton wool and inflammable liquid outside a grandstand at Headingley. [29]

Without adequate evidence it is impossible to show conclusively that the militants deliberately targeted male sport. Sports premises, however, symbolised male leisure. Cricket, rugby and football in Edwardian times were overwhelmingly masculine pursuits, horseracing largely excluded women and while golf clubs tolerated female participants they forced them to abide by male rules and rendered them second-class citizens of the links - as they were of 
the state. Attacking men at play, particularly politicians and other members of the establishment, was a form of retaliation that probably appealed to the suffragettes. Horseracing, the favourite sport of royalty, was an obvious target for the WSPU: Emily Davison not only chose to make her fatal protest on the most important day in the racing calendar, but selected the King's horse as the means of carrying it out.

By the end of 1913, estimated losses to insurers from suffrage attacks had reached $£ 270,000$ according to The Times but Bearman calculates that it may have been as high as $£ 350,000-400,000$. [30] A sizeable percentage involved sports premises, selected for a variety of reasons - location, flammability, lack of protection, economic impact and publicity. It could be argued that the same factors influenced plots to destroy other targets such as churches, private houses, business premises, educational institutions or transport. Sport, however, represented male dominance in a unique way and it therefore seems likely that at least some of the buildings associated with sport were deliberately chosen. This is certainly the view taken by Martin Francis, who suggested that sport's identification with masculine exclusivity explained why Edwardian suffragettes directed many of their actions against the sporting establishment. [31] The fact that British women alone employed this type of violence to publicise their cause and selected sport as a vehicle for its furtherance highlights a major difference between the women's suffrage movements on either side of the Atlantic.

\section{The Sporting Suffragist}

'Her young days were not those of games and much exercise'. [32] Christabel Pankhurst, writing about her mother, Emmeline, sums up a view that continues to be held about British suffragettes: that their dedication to the cause left no time for or interest in sport and leisure. While this may be true of the leadership, some social historians now acknowledge that the majority of suffragists had to fit their political activities into 'ordinary' lives; that for every arsonist, speechmaker and demonstrator there were countless ‘diligent, kind, uninspiring helpers' about whom little is known. [33] The campaign for the vote could not have succeeded without this dedicated army of anonymous foot soldiers but if their political 
contribution has gone unheralded, how much less is known about their day-to-day existence and their recreational pursuits? Sports historians, too, have based many of their views about women's sport on the activities of its leaders, particularly those who implemented sport and exercise programmes in schools and colleges. Some have dismissed sportswomen as not especially emancipated, citing, for example, the willingness of women golfers to play a subordinate role in golf clubs, a situation which still exists today and cannot therefore be seen solely as a weakness of Victorian and Edwardian women. Neil Tranter goes as far as to state that no sportswomen 'played a leading role in the feminist movement.' [34] It turns out that none of these previous viewpoints paints a wholly accurate picture.

Little can be gleaned about sport and leisure from standard works on women's suffrage. Even the most comprehensive reference guide to individual suffragists fails to mention anything as trivial as recreation and other biographical material has concentrated on political activity. [35] We know that the Pankhurst family were members of the Clarion Cycling Club but this was long before suffrage took over their lives. [36] Vera Holme, who often acted as chauffeur to the WSPU leadership, was a friend of Emily Davison and identified by Davison’s biographers as ‘an excellent fly-fisherman'. They also note that the teenaged Emily won a medal for swimming and was said to have been offered lessons for nothing by a 'champion swimmer' at Brighton if she would become professional. [37] The world of male sport has been linked to women’s suffrage through the cricketer, Jack Hobbs. Already a prolific run-scorer with MCC and his county, Surrey, the young Hobbs also seems to have been a suffrage supporter, having 'startled the clubs of Piccadilly' by marching in the men's section of a suffrage procession. Other connections between sport and suffrage merely highlight the physical dangers risked by speakers at public events. When Annie Kenney, WSPU organiser for the West of England, spoke at a Bristol meeting, six professional boxers were apparently hired to keep order and Sylvia Pankhurst, who worked largely in the east end of London, allegedly received 'protection' at her political meetings from a 'local prize fighter', Kosher Hunt. [38] 
Sports history texts have furnished even less detail on suffrage involvement. Jennifer Hargreaves discovered a newspaper article in which Martina Bergman-Osterberg, doyenne of the women's physical education movement, 'naturally thinks that women should have the vote.' There is no suggestion that her thoughts became actions on behalf of suffrage. Sheila Fletcher's examination of women's physical education noted that the Gymnastic Teachers' Suffrage Society was launched in early 1909 and that Rhoda Anstey, Osterberg-trained founder of Anstey College, and her students took part in suffrage processions. Kathleen McCrone added that the Gymnastic Society was the only prominent women’s sports organisation to participate directly in the campaign for the vote, with both golf and hockey associations staying out of the controversy. [39]

However, an unexpected insight into sport and suffrage has been found in a little known volume, The Suffrage Annual and Women's Who's Who (SAWWW), published in 1913. It contains self-penned biographies of more than 650 women who were active in all the major suffrage societies, balancing leaders and well-known militants against unsung supporters who were often officials and committee members of local suffrage branches. Although most of the information relates to suffrage activities, almost $50 \%$ of the entries include an item on recreations; of these 178 women mention sport. Nearly 100 mention only sport, from the predictable tennis, swimming and horse riding to the more adventurous sculling, rock climbing and skiing. The range, listed below, is similar to that identified by Marilyn Constanzo in her review of Edwardian women's sport as seen through the pages of 'Punch', and those enumerated by Catriona Parratt in her analysis of the women's magazine, Womanhood. [40] While The Suffrage Annual has some limitations as a source for suffrage historians, there seems to be no reason why contributors should exaggerate or falsify their leisure pursuits. It is therefore a useful snapshot of the sporting activities of women who are known to have had an active involvement in the suffrage movement. [41]

Cycling is one of the few recreations that has been readily identified with female emancipation. [42] It is therefore no surprise to find it mentioned by nearly $25 \%$ of the women in this sample. But there were also ways in which the bicycle was harnessed to 
political activity. The Elswick Cycle Company was said to have marketed the Elswick bicycle for ladies in the WSPU colours of purple, white and green. The town of Newbury boasted a "bicycling corps of suffragette scouts" who would ride to outlying villages and canvass support. A similar example involves Catherine Marshall, a leading activist in the National Union. Advertising in a suffrage newspaper for helpers in Cumberland, she suggested that a party of friends with bicycles could cover the whole area as speakers and still have time for a holiday in the region, whose charms she enumerated as good bathing and mountain climbing, together with excellent golf links. From this description, she must have assumed that prospective canvassers were women with an interest in sport and the outdoor life. [43]

Golf also appears to be popular with this group of suffrage activists, suggesting that not all female golfers were indifferent to the vote. Furthermore, of the 32 mentioned in the SAWWW, seven were members of the WSPU. Four of these had served prison terms including Charlotte Marsh, paid organiser of the Nottingham branch, and Vera Wentworth, one of a trio who had attacked Asquith on a golf course in Kent in 1909. These were young militants: were they members of golf clubs? If so, how did they square their love of golf with male domination of the golfing community? Could they have condoned attacks on golf courses as part of the campaign of violence? Or were golf course incidents the work of 'wild card' elements within the WSPU? There is no record of their views. It would certainly appear that the leadership had little control of the most militant members of the organisation during the arson campaign. [44]

Table 2

$$
\text { Cycling }
$$$$
\text { Golf }
$$

Tennis

Swimming

Riding

Hunting

Skating

\section{Sports undertaken by Suffrage Women}

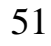

32

22

19

17

12

8
Sculling

Sailing/yachting

Croquet

Shooting

Fishing

Skiing

Badminton
4

4

4

3

3

3

3 


$\begin{array}{lllr}\text { Boating } & 7 & \text { Fencing } & 2 \\ \text { Rowing } & 7 & \text { Bowling } & 1 \\ \text { Hockey } & 5 & \text { Snow-shoeing } & 1 \\ \text { Climbing } & 5 & \text { Gymnastics } & 1 \\ & & \text { Cricket } & 1 \\ & \text { Total } & 215 & \end{array}$

Source: Suffrage Annual and Women's Who's Who

There were other contributors whose sporting talents had enabled them to participate in the public arena. Alice Low, organising secretary of an Edinburgh suffrage society, had represented Scotland in the women's international hockey match against England in 1903. Miss Mary Bridson, honorary secretary of a suffrage society in Bolton, was the writer of several magazine articles on big game shooting. Two others who made a living by the pen were cousins Edith Somerville and Violet Martin. According to John Lowerson, one of the most important contributions to the popularity of foxhunting was provided by the novels of these Irish women who wrote under the joint names of "Somerville and Ross." Edith was Master of the West Carbery Foxhounds and President of the Munster Women’s Franchise League and Violet Martin was a member of two suffrage societies. [45] All of these women combined a knowledge of sport with an interest in politics.

Some entrants in the SAWWW had a professional connection with sport. Dorothy Evans, aged 25 in 1913, was a WSPU organiser in Birmingham and had been imprisoned three times and forcibly fed, but she had trained as a gymnastic teacher at Chelsea Physical Training College. May Lee, Treasurer of the St Albans branch of the National Union, held a first-class diploma from Southport Physical Training College and listed golf as her chief recreation. Of particular interest, however, are the entries of three women who are wellknown in female physical education. Miss Mary Tait, aged 45, wrote that her hobbies were climbing, sailing and photography and that she had spent six years as vice-principal of 
Madame Osterberg’s Physical Training College and two years as principal of Dunfermline College. A history of the latter confirms that she held the position from 1908 till 1910 before resigning in a salary dispute with the Trustees. [46] Louisa Lumsden, pioneering head of St Leonards School, St Andrews, was president of the Aberdeen Society for Women’s Suffrage in 1913; and there is evidence that Margaret Stansfeld, founder and principal of Bedford College, was instrumental in setting up the Bedford Society for Women's Suffrage in her earlier years as a gymnastics teacher. These are the very types of women identified earlier as socially and politically conservative, with no involvement in feminism. Yet it would have been difficult to be both the head of a women's physical education college and a leading participant in the battle for the franchise. Perhaps this is why Margaret Stansfeld's link with suffrage pertained to an early stage in her career and why Mary Tait's membership of three separate suffrage organisations refers to the years after she had ceased to be a college principal. Perhaps it also depends on what is meant by 'a leading role in the suffrage movement'. Not every woman could, or would, have wanted to be, an Emmeline Pankhurst, an Annie Kenney or a Millicent Fawcett. Yet even the latter, president of the NUWSS, mentioned recreations in her SAWWW biography, listing walking, riding and skating, although she conceded that the last two were in her younger days.

Two biographies are particularly interesting, not only for what they reveal in 1913 but because of the subsequent histories of their authors. Teresa Billington-Greig was a very prominent suffragist, co-founder of the Women's Freedom League, who, like many feminists, added her husband's surname to her own on marriage instead of relinquishing her family name. He was the manager of a firm that made billiard tables and in the 1920s she founded the Women’s Billiards Association, becoming its honorary director in 1934. She was also the honorary secretary of the Sports Fellowship whose aim was to interest under privileged girls in athletics. [47] Rose Lamartine Yates, secretary and treasurer of the Wimbledon WSPU, and a friend of Emily Davison, began her Who's Who entry with the statement that she is the only woman councillor out of 68 elected to the Council of the Cyclists Touring Club (CTC), an organisation with which she had been associated for many years. She had met her future 
husband in the CTC and since their marriage, they had cycled extensively in Europe. After her election to London County Council in 1918, she was instrumental in the establishment of Britain’s first cycle lane, in Morden. [48]

\section{Conclusion}

'The vote is ... but a symbol, and the struggle for it but a phase, in the still greater struggle for emancipation in its widest sense.' [49] Many British suffragists, frustrated by a lack of progress towards obtaining the vote, became suffragettes in the early twentieth century and embarked on an increasingly violent campaign against the political establishment. Some of their hostility was directed at sports targets but this did not preclude them from engaging in sport at a personal level. Evidence from the SAWWW indicates that many suffrage supporters took part in the same physical activities that were attracting less politically involved women.

It also has to be recognised that the lives of many ordinary suffrage activists and sportswomen are unrecorded. Few left memoirs, diaries or letters; membership lists of suffrage societies and sports clubs have been destroyed. Perhaps it is unwise to generalise about the interaction of sport and suffrage on the basis of memoirs and biographies of a handful of leading lights in these areas. The thousands of women who joined suffrage societies in the Edwardian era did not necessarily give their every waking moment to 'the cause.' The thousands of women who took part in sport and read about it in the pages of an increasing number of periodicals were not necessarily indifferent to the battle for the vote. There is no reason why the 'average' woman could not have been both a feminist and a sportswoman.

Twenty years ago, Mangan and Park wrote in the introduction to their seminal work From 'Fair Sex' to Feminism, 'there is much still to learn about the relationship of women, sport, recreation and leisure ... to political, social and cultural ideologies.' [50] This survey suggests that many middle-class Edwardian women enjoyed a wide range of hobbies and that 
suffrage activists were no different from the rest. They simply fitted in their sport and leisure alongside the serious business of female emancipation.

\section{Notes}

[1] See, for example, Fowler, 'Why did Suffragettes Attack Works of Art'; Leneman, 'The Awakened Instinct'; Stowell, A Stage of Their Own.

[2] McCrone, Sport and the Physical Emancipation of Women, 278; Tranter, Sport, Economy and Society in Britain, 86; Hargreaves, Sporting Females, 85.

[3] Stanley, Life and Death of Emily Wilding Davison; Crawford, Women's Suffrage Movement, 162-3.

[4] Metcalfe, Woman's Effort, 292; Fulford, Votes for Women, 252; Vicinus, Independent Women, 278; Times, 16 June 1913.

[5] Since Roger Fulford's Votes for Women in 1957, there has been an outpouring of published research on the women's suffrage movement. For a comprehensive list, see Purvis and Holton, Votes for Women, 7-11.

[6] Hamer, 'Fighting for Freedom’, 73; Daily Telegraph, 29 September 2006; Atkinson, 'Deeds not Words', 38.

[7] For example, Vertinsky, The Eternally Wounded Woman; Hargreaves, Sporting Females, 43-47.

[8] Coleman, Adela Pankhurst, 58.

[9] Crawford, Women's Suffrage Movement, 22.

[10] Harrison, Connecting Links, .215; Adickes, 'Sisters not Demons’, 680.

[11] Harrison, Connecting Links, 194.

[12] ibid, 205.

[13] ibid, 190.

[14] Purvis and Holton, Votes for Women, 136; Bearman, 'An Examination of Suffragette Violence', 392.

[15] Hamilton, Golf: Scotland’s Game, 228. 
[16] For further detail on the assaults on politicians, see George, Kay and Vamplew, 'Women to the Fore'.

[17] Golf Illustrated, 21 February 1913, 199 and 28 February 1913, 221. The 'Royal and Ancient sward' refers to the Royal and Ancient Golf Club of St. Andrews (R\&A), the governing authority of the game in Britain. The golf courses there were threatened but not damaged during the campaign.

[18] Watson, Badminton Magazine, 716; Metcalfe, Woman’s Effort, 244.

[19] Bearman, 'An Examination of Suffragette Violence', 378.

[20] Crawford, Women’s Suffrage Movement, 377.

[21] Times, 10 June 1913; Pitt, A Long Time Gone, 342.

[22] Times, 8 December 1913.

[23] Harrison, Separate Spheres, 189: Crawford, Women’s Suffrage Movement, 82.

[24] from Daily News, 29 April 1913, quoted in Marlow, Votes for Women,189.

[25] Times, 21 April 1914; Bearman, 'An Examination of Suffragette Violence’, 368, 372 Bearman calculates that there were 232 suffragette attacks in 1913 but only 105 in 1914, averaging 21 per month in 1913 and 15 in 1914. Estimates for Scotland alone suggest 8 sports targets out of 43 in 1913 but none out of 20 in 1914 (calculated from Leneman, A Guid Cause, Table 2, 274-278).

[26] Adickes, ‘Sisters not Demons’, 684.

[27] Bearman, 'An Examination of Suffragette Violence', 372.

[28] Mitchell, The Hard Way Up, 176.

[29] Crawford, Women's Suffrage Movement, 377; Leneman, A Guid Cause, 143; Times, 26 November 1913.

[30] Times, 21 April 1914; Bearman, ‘An Examination of Suffragette Violence’, 368-369.

[31] Francis, 'Leisure and Popular Culture’, 236; McCrone, Sport and the Physical Emancipation of Women, 277.

[32] Pankhurst, Unshackled, 17. 
[33] Holton, 'The Suffragist and the “Average Woman”, 11; Crawford, Women’s Suffrage Movement, 66 - a phrase used to describe Mary Blathwayt, one of the few rank-and-file workers who left a diary of her suffrage experiences. A member of the WSPU for six years, she had led a sheltered upper-middle class life but was very fond of swimming and cycling and was particularly 'enthusiastic for the village rifle club’ - Willmott Dobbie, A Nest of Suffragettes in Somerset, 10.

[34] Tranter, Sport, Economy and Society in Britain, 92; McCrone, Sport and the Physical Emancipation of Women, 278.

[35] Crawford, Women's Suffrage Movement.

[36] Coleman, Adela Pankhurst, 20.

[37] Stanley, Life and Death of Emily Wilding Davison, 12 - it is not clear what the authors meant by 'professional', see further refs, 114 .

[38] Holton, 'Manliness and Militancy', 114,120; Willmott Dobbie, A Nest of Suffragettes in Somerset 9-56.

[39] Hargreaves, Sporting Females, 77; Fletcher, Women First, 71; McCrone, Sport and the Physical Emancipation of Women, 278.

[40] Constanzo, “'One Can’t Shake Off the Women”, 34; Parratt, 'Athletic “Womanhood”', 144.

[41] R., A.J. The Suffrage Annual; for example, the entries vary considerably in length and content, and are not representative of the strength of individual suffrage societies. This in no way invalidates their use for present purposes. For a critique of the SAWWW see Kay, 'No Time for Recreations till the Vote is Won', 2-4.

[42] Holt, Sport and the British, 12-4; McCrone, Sport and the Physical Emancipation of Women, 182-4.

[43] Pugh, The March of the Women, 219; Atkinson, The Suffragettes in Pictures, 14; quoted in Marlow, Votes for Women.

[44] Bearman, ‘An Examination of Suffrage Violence’, 393.

[45] Lowerson, 'Foxhunting’ 432. 
[46] MacLean, History of Dunfermline College, 56.

[47] Crawford, Women's Suffrage Movement, 56.

[48] UK Newsquest Regional Press - This is Local London, 2 April 2003.

[49] Metcalfe, Woman’s Effort, 363.

[50] Mangan and Park, From 'Fair Sex' to Feminism, 9.

\section{References}

Adickes, Sandra, Sisters not demons: the influence of British suffragists on the American suffrage movement, Women’s History Review, 11, 4, 2002: 675-690.

Atkinson, Diane, The Suffragettes in Pictures. Stroud: Museum of London/Sutton Publishing, 1996.

Atkinson, Diane, ‘Deeds not Words’. New Statesman, 6 June 2005: 38-41.

Bearman, C.J., 'An Examination of Suffragette Violence'. English Historical Review, CXX, 486 (2005): 365-394.

Coleman, Verna, Adela Pankhurst: The Wayward Suffragette 1885-1961. Melbourne:

Melbourne University Press, 1996.

Constanzo, Marilyn, ““One Can’t Shake Off the Women”: Images of Sport and Gender in Punch, 1901-10', International Journal of the History of Sport, 19 (2002): 31-56.

Crawford, Elizabeth, The Women's Suffrage Movement: A Reference Guide 1866-1928.

London: Routledge, 2000.

Daily Telegraph.

Fletcher, Sheila, Women First: The Female Tradition in English Physical Education 18801980. London: Athlone, 1984.

Fowler, Rowena, 'Why did Suffragettes Attack Works of Art', Journal of Women's History, 2 (1991): 109-125. 
Francis, Martin, 'Leisure and Popular Culture' in Zweiniger-Bargielowska, Ina, Women in

Twentieth-Century Britain: Social, Cultural and Political Change. London: Longman/Pearson, 2001.

George, Jane, Kay, Joyce and Vamplew, Wray, 'Women to the Fore: Gender

Accommodation and Resistance at the British Golf Club before 1914'. Sporting Traditions,

24, 1 (2007).

Golf Illustrated 1913.

Hamer, Emily, 'Fighting for Freedom: Suffragette Violence against their State' in Alice

Myers and Sarah Wight eds., No Angels: Women who Commit Violence (London, 1996).

Hamilton, David, Golf: Scotland's Game. Ayrshire, 1995.

Hargreaves, Jennifer, Sporting Females: Critical Issues in the History and Sociology of

Women’s Sports. London: Routledge, 1994.

Harrison, Patricia Greenwood, Connecting Links: the British and American Woman Suffrage

Movements 1900-14. Westport: Greenwood Press, 2000.

Holton, Sandra Stanley, 'The Suffragist and the “Average Woman”'. Women’s History

Review, 1, 1 (1992): 9-24.

Holton, Sandra Stanley, 'Manliness and Militancy: the political protest of male suffragists and the gendering of the "suffragette” identity' in John, A. and Eustance, C. eds., The Men's Share. London: Routledge, 2000.

Kay, Joyce, 'No Time for Recreations till the Vote is Won? Suffrage Activists and Leisure in Edwardian Britain’. Women’s History Review, 16, 4, 2007: 535-553.

Leneman, Leah, A Guid Cause: The Women's Suffrage Movement in Scotland. Edinburgh: Mercat, 1995.

Leneman, Leah, ‘The Awakened Instinct: Vegetarianism and the Women’s Suffrage Movement in Britain'. Women’s History Review, 6, 2, 1997: 271-287.

Lowerson, John, ‘Foxhunting’ in Christensen, Karen, Guttmann, Allen and Pfister, Gertrud eds. International Encyclopedia of Women and Sports, Vol. 1. New York: Macmillan, 2001. 
McCrone, K.E., Sport and the Physical Emancipation of Women. London: Routledge, 1988.

MacLean, Isabella, The History of Dunfermline College of Physical Education. Edinburgh:

Blackwood, 1976.

Mangan, J.A. and Park, Roberta J., From 'Fair Sex' to Feminism: Sport and the Socialization of Women in the Industrial and Post-industrial Eras. London: Cass, 1987.

Marlow, Joyce ed. Votes for Women - the Virago Book of Suffragettes. London: Virago, 2000.

Metcalfe, A.E., Woman’s Effort. Oxford: Blackwell, 1917.

Mitchell, George ed. The Hard Way Up: the Autobiography of Hannah Mitchell. London: Virago, 1977.

Pankhurst, Christabel, Unshackled: The Story of How We Won the Vote. London: Hutchinson, 1959. (this edition 1987).

Pitt, Chris, A Long Time Gone. Halifax: Portway, 1996.

Purvis, June and Holton, Sandra Stanley eds. Votes for Women. London: Routledge, 2000.

R., A.J. ed. The Suffrage Annual and Women’s Who's Who. London: Stanley Paul, 1913.

Stanley, Liz with Morley, Anne, The Life and Death of Emily Wilding Davison. London:

Women’s Press, 1988.

Stowell, Sheila, A Stage of Their Own: feminist playwrights of the suffrage era. Manchester: MUP, 1992.

The Suffragette.

The Times.

Tranter, Neil, Sport, Economy and Society in Britain, 1750-1914. Cambridge: CUP, 1998. Vertinsky, Patricia, The Eternally Wounded Woman: Women, Exercise and Doctors in the late Nineteenth Century. Manchester: MUP, 1990.

Vicinus, Martha, Independent Women: Work and Community for Single Women 1850-1920.

London: Virago, 1985.

Watson, Alfred E.T. ed. Badminton Magazine, 36, 1913. 
Willmott Dobbie, B.M., A Nest of Suffragettes in Somerset - Eagle House, Batheaston.

Batheaston: Batheaston Society, 1979.

Joyce Kay

Department of Sports Studies

University of Stirling

Stirling FK9 4LA

Scotland

UK

joyce.kay@stir.ac.uk 
